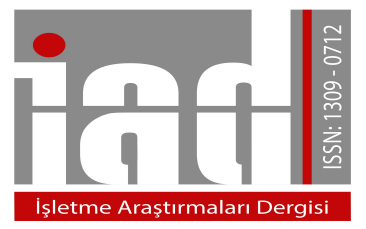

\author{
İşletme Araştırmaları Dergisi \\ Journal of Business Research-Turk \\ 10/3 (2018) 350-361
}

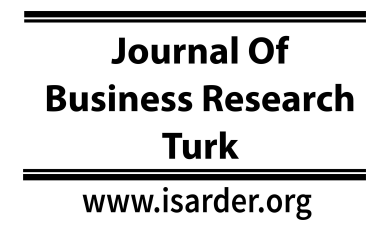

\title{
Moderating Role of Job Satisfaction on the Relation between Leadearship Styles and Organizational Silence ${ }^{1}$
}

\author{
Ömer TURUNÇ \\ Süleyman Demirel University \\ Faculty of Economics and Administrative \\ Sciences, Isparta, Turkey \\ orcid.org/0000-0003-2234-6523 \\ omert21@gmail.com \\ Hakan TURGUT \\ Başkent University \\ Faculty of Fine Arts, Des. And Arc. \\ Ankara, Turkey \\ orcid.org/0000-0002-4572-194X \\ hakanturgut66@gmail.com
}

\author{
Abdullah ÇALIȘKAN \\ Toros University \\ Department of Health Management \\ Mersin, Turkey \\ orcid.org/0000-0001-5746-8550 \\ abdullah.caliskan@toros.edu.tr \\ İbrahim Sani MERT \\ Antalya Bilim University \\ Faculty of Economics and Administrative \\ Sciences, Antalya, Turkey \\ orcid.org/0000-0002-2850-1865 \\ sanimert@gmail.com
}

\begin{abstract}
The purpose of this study is to determine the effect of transformational and conditional-rewarding leadership on the organizational silence perceptions of workers and the moderating role of satisfaction in this relation. Validity of the scales was proved with Confirmatory Factor Analysis (CFA) performed with Structural Equation Modelling (SEM). Relations between the variables mentioned were tested with hierarchic regression analyses and their moderating effects were researched according to data obtained. In the study, private hospitals active in the health sector in Isparta province were taken into consideration. Data was obtained from questionnaires filled out by 396 hospital employees and relations between the variables were analyzed based on the collected data. At the end of the study, it was determined that transformational and conditional-rewarding leadership has a diminishing role on the organizational silence perceptions of workers and that job satisfiction plays a moderating role in the relation between transformational and conditional-rewarding leadership and pro-social silence which one of the organizational silence dimensions.
\end{abstract}

Keywords:Transformational leadership, conditional-rewarding leadership, organizational silence, job satisfaction.

\footnotetext{
${ }^{1}$ This work was presented as a paper at the 17 th International Participatory Business Congress and it was published as a summary in the conference proceedings book.
} 


\section{Introduction}

Workers feel better in the work environment where they easily explain and discuss their ideas and proposals, where they put forward problems and their solution proposals in the business. They can be more productive and effective in terms of both themselves and the businesses. In some businesses, opinions and proposals of the workers are not paid attention. Workers who want to share their opinions are prevented in various ways and naturally an organization climate where in-business share becomes much less in time forms. (Kiliç et al., 2014) The effect of the leader in the formation of this climate and which leadership style is applied are important.

In the changing and developing work life, the effect of organizational success on the attitudes and behaviours of the workers has started to become different. Emerging of new organizational variables and their effects' being revealed contributes to increase in awareness in the business life. Organizational silence faces us as a variable which is believed to have important results in the modern work life on which they have been often studied recently. The variable, which is investigated as both input and output one, can interact with many organizational variables and cause different results.

In this study, the relation between the leadership styles and organizational silence was tried to be revealed and whether job satisfaction has a role in this relation was examined. Developed hypotheses with an empirical research conducted in the health sector were analysed. Findings obtained were evaluated and practical proposals were tried to be reached.

\section{Conceptional Framework}

In this study, relations between the variables, Transformational Leadership (TL), conditional rewarding leadership (CRL), organizational silence (OS) and job satisfaction (JS), which were handled as leadership styles, were examined within the scope of the research model formed.

Organizational Silence means an effective and important process regarding cost and labour saving for the businesses. Whether organizational silence is effective in the productivity development and improvement programs of the organizations changes depending on the attitude of the managers (Yalçınsoy, 2017). It may be stated that many factors which are personal, organizational or which originate from the environment. (Moçoşoğlu and Kaya, 2018)

Organizational silence, which is the first one of the variables in our study, and which was examined as a dependent variable, is a situation where workers do not share their solutions or proposals with their managers after they have evaluated a problem or a matter related to work they perform behaviourally, cognitively and emotionally (Pinder and Harlos, 2001:341). Even if the term OS is perceived as a sign of loyalty of the workers to the organization, the reality is that it emerges as a negative condition for the organizations when it is defined as that workers hide them intentionally even if they have knowledge and an opinion related to the organizational matters and problems (Çakıc1, 2010: 9). When it is considered that motivation capacities of individuals with such thoughts will be less, organizational silence is a condition which annoys and upsets workers, but which is also very common (Blatt et al., 2006: 913; Çalışkan and Pekkan, 
2017: 4). With this aspect, OS is seen as a potential threat against organizational change and development, too (Daşçı and Cemaloğlu, 2016: 32-45). When workers prefer to be silent intentionally, or when they cannot speak out, they become nervous and stressful. This dilemma affects the motivation of workers negatively (Brinsfield, 2009: 62). OS has three sub-dimensions, Acquiescent Silence (AS), Defence Silence (DS) and Prosocial Silence (PS).

Leadership, which is one of the independent variables whose effect on organizational silence is investigated, is an important variable which was and has been studied. Many studies were conducted for the terms of leadership and leader and with those studies, the terms were tried to be defined and explained from the beginning again (Tengilimoğlu, 2005:2). Leaders display against events they encounter is a situation which leadership style they have chosen uncovers. Within the scope of this understanding, they have to prevent their followers from coming upon unusual situations in order to form a stable group (Hicks and Gullert, 1981:234).

In this study, transformational leadership (TL) and conditional rewarding leadership (CRL) styles were examined and they were included in the analyses. Transformational Leaders direct their followers towards success and development, teaching them that the purpose is not only to exist. They carry it out by enabling them to understand themselves and their self-reliance to develop (Y1ld1z, 2002: 233). Followers of transformational leaders trust, respect and believe in them (Bass, 1990).

In some studies related to this subject conducted in the literature, Transformational leadership styles come to the forefront as one of the leadership approaches which will reduce organizational silence as much as possible. In the studies conducted by Bakmunkh (2011: 101), Köse (2013), Erol (2012: 80-83) and Bildik (2009: 67-72), the results show the transformational leadership style reduces silence environment that may form in the organization.

Interactional leaders in the Conditional Rewarding Leadership (CRL) style, which is explained as one of the three dimensions of interactional leadership, (Conditional rewarding leadership, management by exception, laissez-faire leadership), utilize conditional rewards in order to encourage their followers in suitable or required behaviour and to prevent their unsuitable behaviours (Podsakoff et al., 1990). Interactional leader used their authorities to reward their followers who show higher performance. These rewards granted may be tangible or related to status. The subordinates have the required information about those expected from them (Morçin and Morçin, 2013).

Job satisfaction, which was handled as an independent and moderating variable in the study, is a term which has important effects on the attitudes and behaviours of the workers and which expresses that how happy the workers are with their works. (Mrayyan, 2005). The other definition of job satisfaction is the name given to emotional response that a worker gives as a result of his comparison he expects from his job and those he gets from his job (Samad, 2006). Whereas Robinson et al. (2000) evaluated job satisfaction as a general attitude of workers towards their works, Luthans (1995) expressed that it is a result of perception of how much the job meets the things important to them.

Under the light of these evaluations, the model of the research is in Figure 1. H1 and sub-hypotheses were prepared on the basis of the literature, in order to test the 
relations between TL and OS and sub-dimensions, $\mathrm{H} 2$ and sub-hypotheses to test the relations between CRL and OS and sub-dimensions, $\mathrm{H} 3$ and $\mathrm{H} 4$ to test relations between TL and CRL and JS whose moderatingness is researched, H5 and subhypotheses to test relations between JS and OS and sub-dimensions, $\mathrm{H} 6$ and $\mathrm{H} 7$ to test moderating effect of JS on the relation between TL with sub-dimensions and CRL and OS and sub-dimensions.

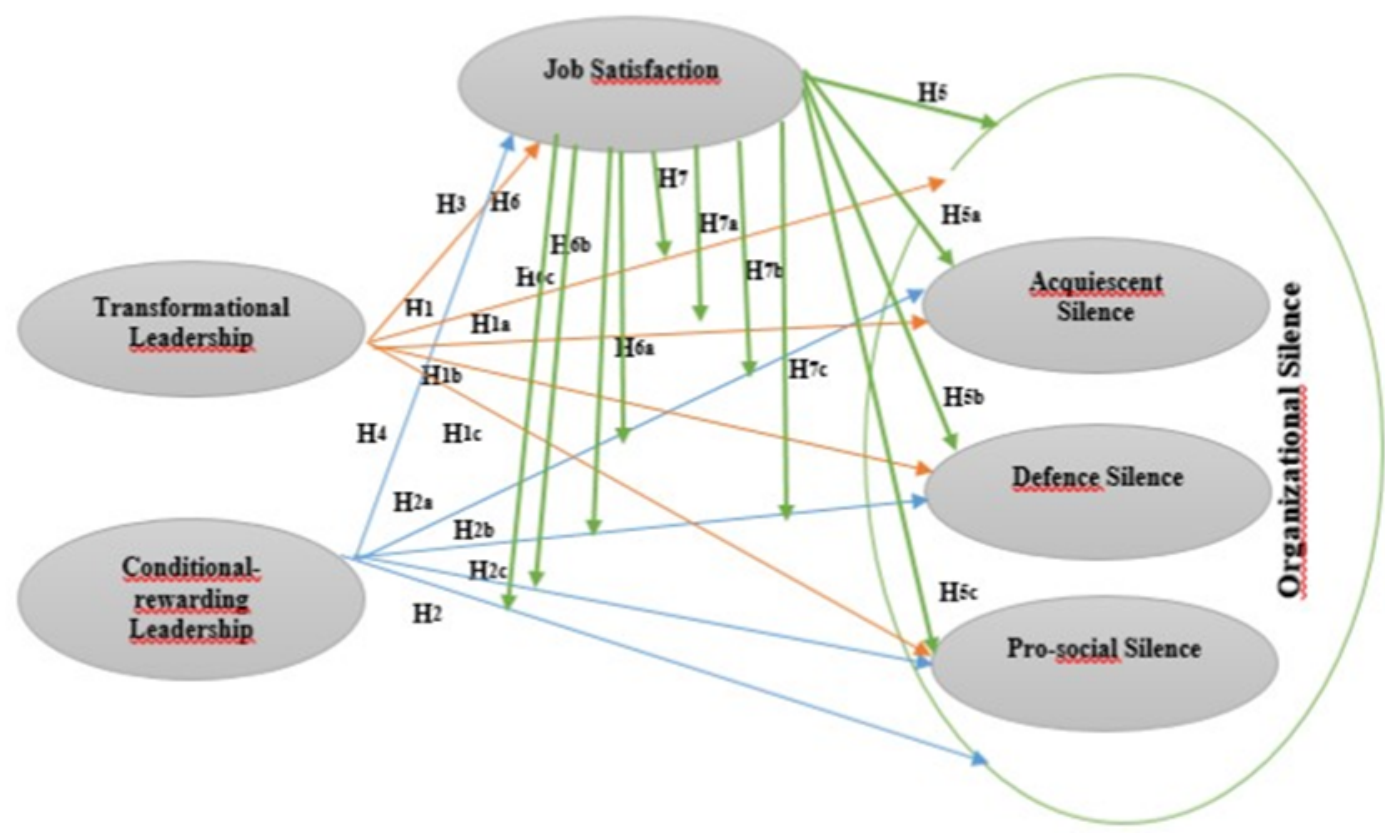

Figure 1. Model of the Research

\section{Method}

\subsection{Data Collection Method and Sampling}

Questionnaire method was used as a data collection tool in the research. The questionnaire comprises 2 sections and total 39 questions. In the first section is demographic information and in the second section are questions about TL and CRL, which are independent variables, and dependent variable OS and JS which is our moderating variable. Web-based Questionnaires were sent via internet, and published ones were delivered by hand to the related personnel.

Health workers working in the private health businesses active in Isparta comprise the universe and samples of the study with the subject called role of job satisfaction in the effect of Leadership Styles on Organizational Silence. Various analyses related to the model formed under the light of usable 396 questionnaires $(n=396)$ obtained from the samples were performed. 396-person sample size reached in the study was seen to represent the universe with 0,99 reliability and 0,10 sampling error (Yazıcığlu and Erdoğan, 2004: 49-50). After confirmatory factor analyses, hypotheses and moderating effects were tested with hierarchic regression analysis with three stages proposed by Baron and Kenny (1986). Moderating effects were tested with regression curves. Hypotheses and the structured research model are in Figure 1. 


\subsection{Scales of the Research:}

3.2.1. Organizational Silence Scale: When measuring the OS levels of the workers, OS scale developed by Van Dyne et al. (2003) and used by Cem Kahya (2013). The scale was structured with 15 questions to gauge the 3 dimensions. The scale has three sub-dimensions, Acquiescent Silence (AS), Defence Silence (DS) and Prosocial Silence (PS). The result of KMO analysis of the scale is .70 and above for all dimension and total scale. Barlett test was found to be meaningful $(p=.000)$. Cronbach Alpha coefficients of reliability analyses performed by Cem Kahya (2013) were found to be $.88, .88, .80$ respectively and total reliability .74 . As a result of reliability analysis performed, Cronbach Alpha coefficients for OS, AS, DS and PS were found to be .85, $.87, .93, .82$ respectively. Total variance imparted for three dimensions is .75 .

3.2.2. Transformational and Conditional Rewarding Leadership Scales: Scales with 5 and 4 items respectively developed by Podsakoff et al. (1990; 1996), was used in order to determine TL and CRL styles in the businesses. Both scales have a single dimensional structure. Cronbach Alpha coefficients of reliability analyses performed by Bettencourt (2004) were found to be .93 and .95 respectively. As a result of reliability analyses, total Cronbach alpha coefficients were found to be .92 and .94 respectively. Variances imparted are .80 for TL and .85 for CRL.

3.2.3. Job Satisfaction Scale: 5 -item scale developed by Arnett (1999) and Judge et al. (2009) was used in order to determine JS level perceived in the businesses. JS scale, which was included in the model as a moderating variable, is a single-dimension one. Judge et al. found that Cronbach alpha coefficient for JS was .79. As a result of reliability analysis performed, total Cronbach alpha coefficient of the scale was found to be .81 . Variance imparted was .66 .

\subsection{Validity and Reliability of the Scale:}

SPSS packet program was used for reliability tests of the scales, and AMOS packet program for confirmatory factor analyses and structural equation models. Cronbach Alpha coefficients were found for reliabilities of the scales and confirmatory factor analyses were performed to determine whether they were valid. The findings related to these tests are in Table 1. After then, correlation relations between the variables were determined (Chart 2).

\section{Chart 1:}

Values for Goodness of Fit of the scales as a result of confirmatory factor analysis

\begin{tabular}{|c|c|c|c|c|c|c|c|c|c|}
\hline Variables & $\mathbf{X}^{2}$ & df & $\begin{array}{c}\text { CMIN/ } \\
\text { DF } \\
\leq 5\end{array}$ & $\begin{array}{l}\text { GFI } \\
\geq .85\end{array}$ & $\begin{array}{c}\text { AGFI } \\
\geq .80\end{array}$ & $\begin{array}{l}\text { CFI } \\
\geq .90\end{array}$ & $\begin{array}{l}\text { NFI } \\
\geq .90\end{array}$ & $\begin{array}{r}\text { TLI } \\
\geq .90\end{array}$ & $\begin{array}{c}\text { RMSEA } \\
\leq .08\end{array}$ \\
\hline 1. Org.Silence(OS) & 130,2 & 78 & 1,67 & 0,96 & 0,94 & 98 & 0,97 & 0,98 & 0,04 \\
\hline 2.Acq.Silence(AS) & 106 & 46 & 2,3 & 0,95 & 0,91 & 0,96 & 0,99 & 0,98 & 0,05 \\
\hline 3. Defence Silence (DS) & 176,7 & 57 & 3,1 & 0,96 & 0,92 & 0,98 & 0,96 & 0,94 & 0,07 \\
\hline 4.Pro-social silence(PS) & 97,2 & 36 & 2,7 & 0,97 & 0,94 & 0,93 & 0,95 & 0,97 & 0,06 \\
\hline 5. Job Satisfaction (JS) & 2,10 & 1 & 2,1 & 0,99 & 0,97 & 0,99 & 0,99 & 0,99 & 0,05 \\
\hline 6. Transform. L(TL) & 8,9 & 4 & 2,2 & 0,99 & 0,96 & 0,99 & 0,98 & 0,98 & 0,05 \\
\hline 7. Cond.Rev. L.(CRL) & 3,2 & 1 & 3,2 & 0,99 & 0,95 & 0,99 & 0,99 & 0,99 & 0,07 \\
\hline
\end{tabular}

Note: Goodness of fit value intervals were organized according to "acceptable" standards. Pearson correlations were calculated in order to determine the relations 
between the variables (Chart 2). Reliability findings were presented in (parenthesis) at the end of rows in the Table. At the end of the analysis, it is seen that TL and SL which were handled as leadership styles, have meaningful relations with organizational silence and its some dimensions and job satisfaction.

\section{Chart 2:}

Average, S. Deviation and Correlation Values

\begin{tabular}{lccccccccc}
\hline Variables & Ort. & $\boldsymbol{S . ~} \boldsymbol{S}$ & $\mathbf{1}$ & $\mathbf{2}$ & $\mathbf{3}$ & $\mathbf{4}$ & $\mathbf{5}$ & $\mathbf{6}$ & $\mathbf{7}$ \\
\hline 1. Org. Silence (OS) & 2,36 & .88 & $\mathbf{( , 8 2 )}$ & & & & & & \\
2. Acq. Silence (AS) & 2,52 & .89 &, $92^{* *}$ & $\mathbf{( , 8 7 )}$ & & & & & \\
3. Def. Silence (DS) & 2,21 & .99 &, $94^{* *}$ &, $75^{* *}$ & $\mathbf{( , 9 3 )}$ & & & & \\
4. Pro-so. Silen (PS) & 4,07 & .77 &,- 06 &,- 05 &,- 06 & $\mathbf{( , 8 2 )}$ & & & \\
5. Job Satisfa. (JS) & 3,65 & .87 &,$- 23^{* *}$ &,$- 18^{* *}$ &,$- 26^{* *}$ &, $18^{* *}$ & $\mathbf{( , 8 0 )}$ & & \\
6. Transf. L. (TL) & 3,54 & .97 &,$- 12^{*}$ &,- 03 &,$- 19^{* *}$ &, $23^{* *}$ &, $45^{* *}$ & $\mathbf{( , 9 3 )}$ & \\
7. Cond.Rev.L.(CRL) & 3,62 & 1,02 & $-.15^{* *}$ &,- 08 &,$- 19^{* *}$ &, $18^{* *}$ &, $44^{* *}$ &, $73^{* *}$ & $\mathbf{( , 9 5 )}$ \\
\hline
\end{tabular}

Not: Alpha coefficients are in parentheses.

$* p \leq .05 .{ }^{*} p \leq .01$

\section{Analysis of the Data and Findings}

Data obtained as a result of the research were analysed on SPSS and AMOS programs. Within this scope, moderating effects were investigated with three-stage hierarchic regression analysis proposed by Baron and Kenny (1986). Moderating effects were tested with regression curves.

In order to test the hypothesis in the study aimed at determining effect of TL and CRL on OS and moderating role of JS in this effect, hierarchic regression analyses were performed.

In the hierarchic regression analysis carried out to test the hypotheses, TL and CRL were included in the study as the independent variables separately, OS and subdimensions (AS, DS, PS) as the dependent variables and JS as the moderating variable. As a result of many analyses performed, only 3 moderating effect were determined. They are in Chart 3. TL, CRL and JS were centred while being included in the model. (Cohen et al., 2003).

\section{Chart 3:}

Results of Moderating Effect Analysis

\begin{tabular}{lccc|lccc}
\hline & \multicolumn{3}{c}{ Pro-social Silence (PS) } & \multicolumn{3}{c}{ Pro-social Silence (PS) } \\
\hline Step & 1 & 2 & 3 & Step & $\mathbf{1}$ & $\mathbf{2}$ & $\mathbf{3}$ \\
\hline TL & $.23^{* * *}$ & $.19 * *$ & $.20^{* * *}$ & CRL & $.18^{* * *}$ & $.13^{*}$ & $.14^{*}$ \\
JS & & .09 & .10 & JS & & $.12^{*}$ & $.13^{*}$ \\
TLxJS & & & $.10^{*}$ & SLxJS & & & $.10^{*}$ \\
$A R^{2}$ & .06 & 00 & .02 & $A R^{2}$ & .03 & .01 & .01 \\
$\Delta F$ & $22,2 * * *$ & $12,6^{* * *}$ & $9,8^{* * *}$ & $\Delta F$ & $13,6^{* * *}$ & $9,3^{* * *}$ & $7,6^{* * *}$ \\
\hline$* p \leq .05, * * p \leq .01, * * * p \leq .001$ & & & &
\end{tabular}

Moderating Variable is a variable which affect the strength and direction of the relation between independent variable and dependent variable (Baron and Kenny, 1996: 1174). According to results of multi-regression analysis in Chart 3, moderating effect of JS was investigated. At the end of the analysis, it was seen that JS has a moderating 
effect on the relation between TL and PS $(\beta=.10, p \leq 05)$. At the end of analyses, it was also seen that JS has a moderating effect on the relation between SL and PS ( $\beta=.10$, $\mathrm{p} \leq 05$ ). Besides, the process proposed by Cohen et al. (2003) was followed in order to carry out a more detailed investigation related to the direction of the relation. Within this scope, when JS, which is the moderating variable, is low and high, meaningfulness of the relations between TL and PS was tested with regression curve drawn (Aiken and West, 1991).

As seen in Figure 2, even if the relation between TL and PS is meaningful when JS perception is both low and high, it is seen that TL-PS interaction is higher when JS is high. As a result of TL-JS interactions, $7 \%$ of total variance of the model was determined to be revealed. So, Hypothesis 7c was supported. That is, JS has a moderating effect within the scope of this relation.

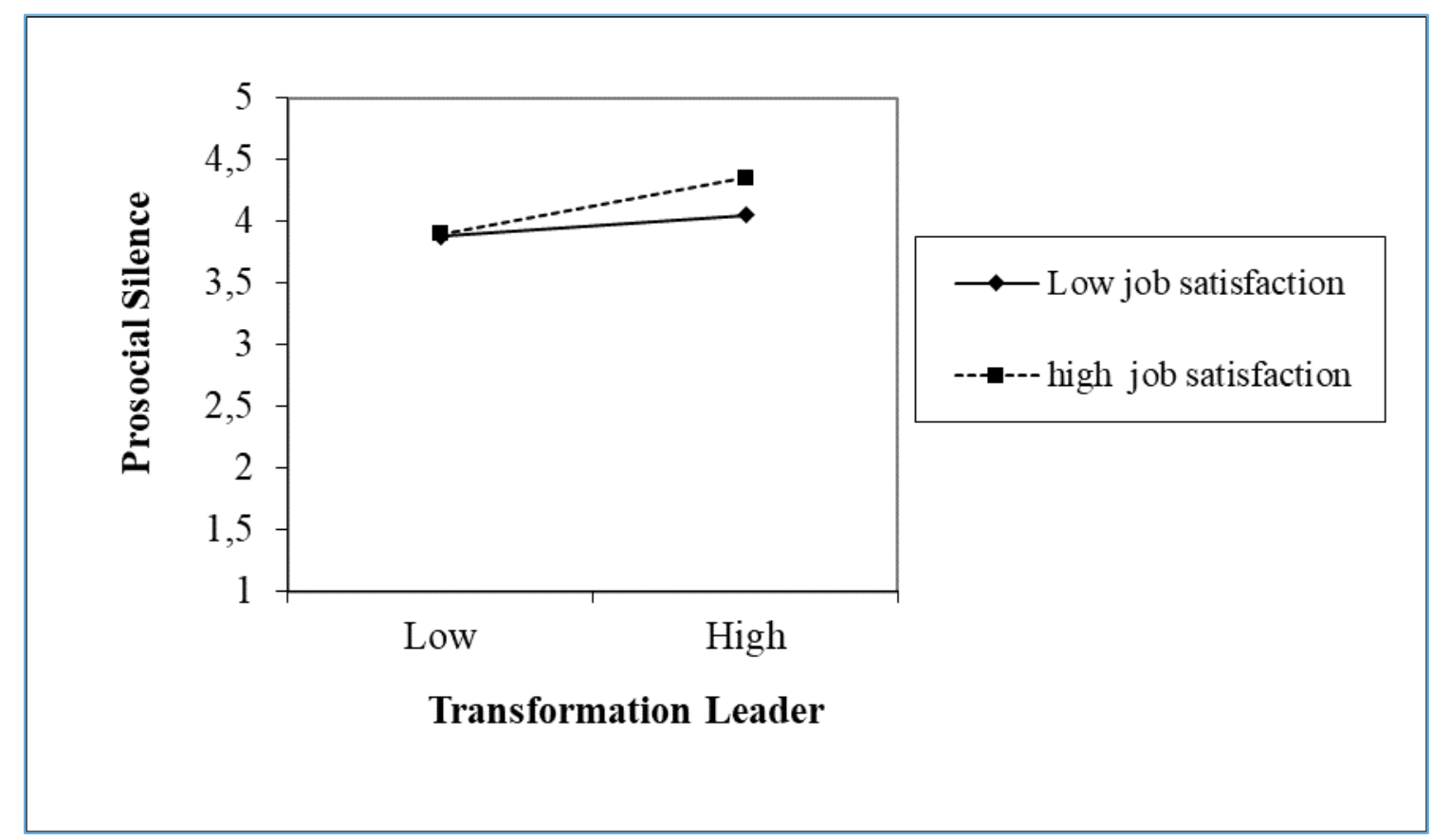

Figure 2. Moderating Relations

As seen Figure 3, even if the relation between CRL and PS is meaningful when JS perception is both low and high, it is seen that TL-PS interaction is higher when JS is high. As a result of SL-JS interactions, 6\% of total variance of the model was determined to be revealed. So, Hypothesis $6 \mathrm{c}$ was supported. That is, JS has a moderating effect within the scope of this relation. 


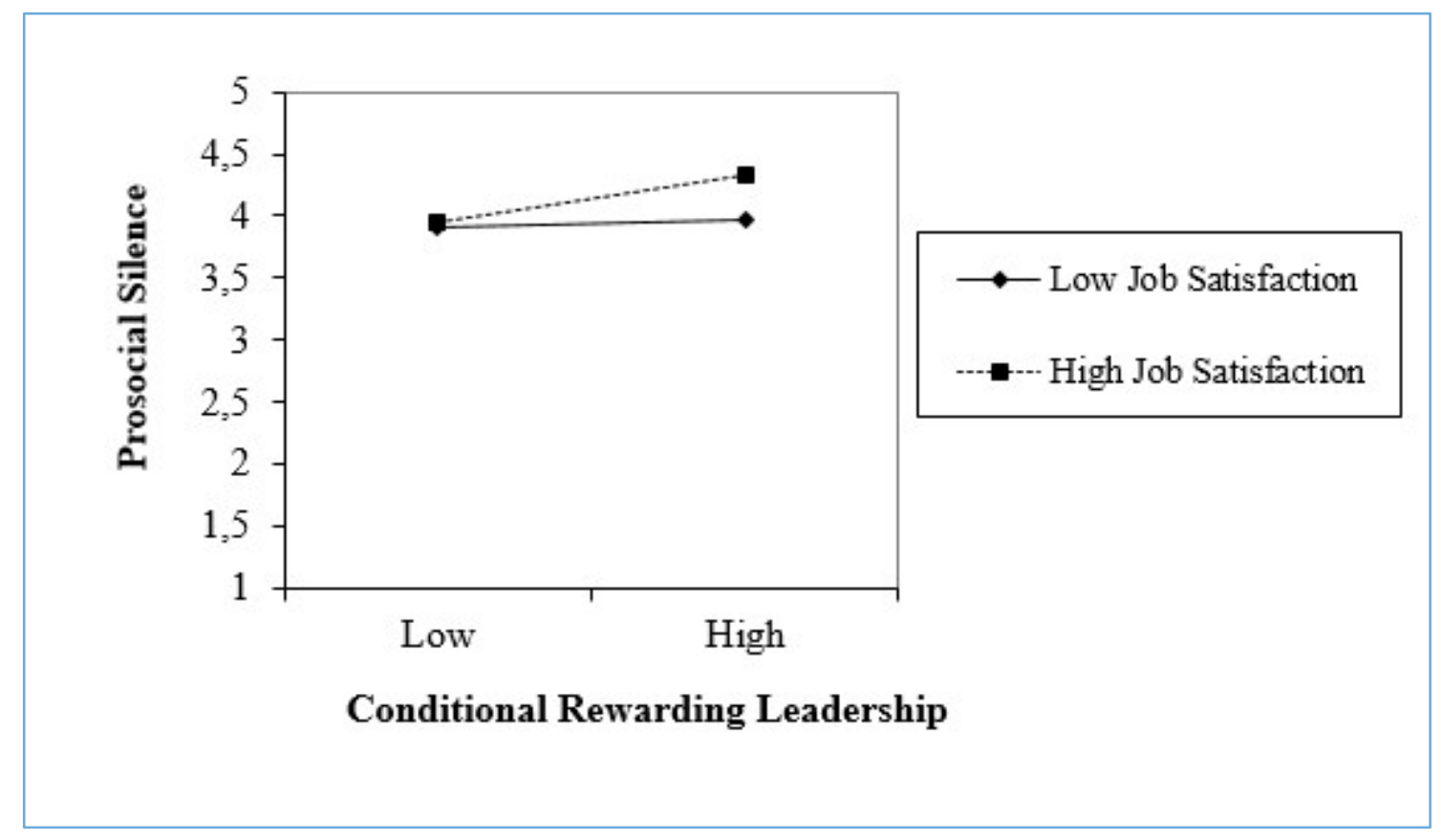

Figure 3. Moderating Relations

Within the scope of findings obtained as a result of analyses performed, test results of the hypotheses are presented in Figure 4 as a whole.

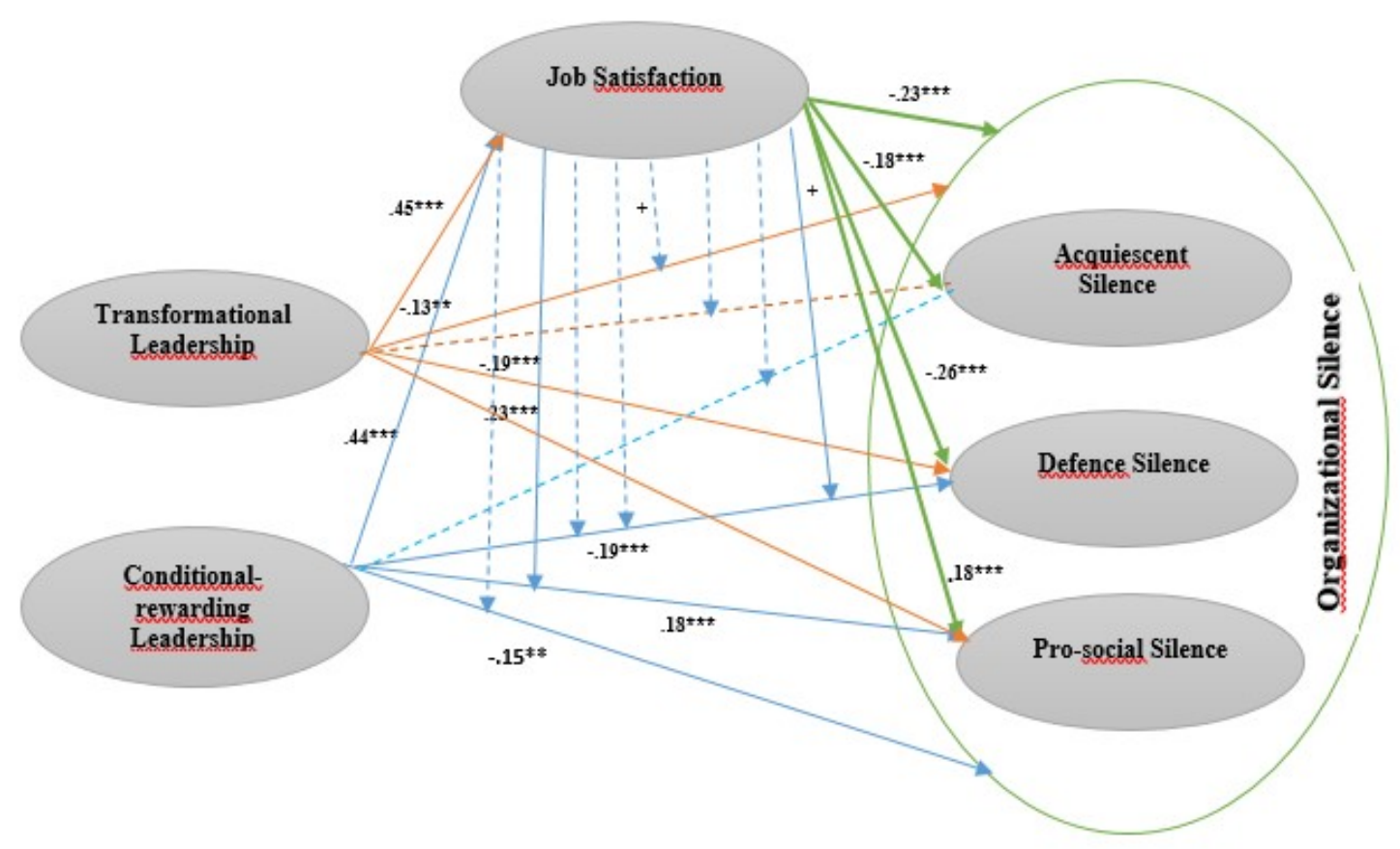

Figure 4. Test Results of the Hypotheses 


\section{Discussion and Conculusion}

In this study, the relation between leadership styles and organizational silence was tried to be revealed and moderating role of job satisfaction in this relation was investigated. Hypotheses developed with an empirical investigation carried out on the workers of health sector in Isparta. As a result of the findings obtained, it was determined that transformational and conditional rewarding leadership styles which were included in the study within the scope of leadership styles having an important role in the work life have effects of reducing organizational silence. This finding is compatible with the theory and similar investigations. (Bakmunkh, 2011; Köse, 2013; Erol 2012; and Bildik, 2009).

It is expected that all terminal outputs, such as in-organization productivity, performance, etc. of the workers who adopt silence within the organization and who try to practice this silence in their attitudes and behaviours, will be low (Çalışkan and Pekkan, 2017: 15). Therefore, that workers' behaviours of remaining silent should be reduced with leadership applications such as transformational leadership and conditional rewarding leadership, etc. was revealed is one of the important results of the study

In addition, it was seen in the study that leadership styles increase job satisfaction. It was found in the literature that similar results were obtained before (Tanriverdi and Paşaoğlu, 2014). It was determined that both leadership behaviours have reducing roles on the organizational silence in parallel with the results obtained in the previous researches (Erol and Köroğlu, 2013). It was seen that job satisfaction, which was handled as a moderating variable, is also a variable reducing organizational silence and sub-dimensions.

As a result of moderating effect analyses, it was determined that job satisfaction has a moderating effect only on the relation between transformational and conditional rewarding leadership and pro-social silence. It is thought that this finding originates from the nature of pro-social silence dimension. As a result, an individual prefers to be silent not because he is afraid of negative results to emerge when he speaks out but because he wants to protect the organization and the others from damages that may occur in this silence type.

Within this scope, it was evaluated that the finding obtained may have resulted from that positive leader behaviours may interact differently from other silence types and pro-social silence. The study has various limitations. samples are limited and the study is not longitudinal. Academicians to make researches in the future may be suggested to study on moderating role of demographic variables in OS leadership relations. 


\section{References}

Aiken, L. S. ve West, S. G. (1991). Multiple Regression: Testing and Interpreting Interactions, Los Angeles, CA: Sage.

Arnett, J. J. (1999). Adolescent Storm And Stress, Revisited, American Psychologist, 54(5), 317-326.

Batmunkh, M. (2011). "Lider Tarzları İle Örgütsel Bağl1lık ve Örgütsel Sessizlik Arasındaki İlişki ve Bir Araştırma", Marmara Üniversitesi Sosyal Bilimler Enstitüsü Yayımlanmamış Yüksek Lisans Tezi, İstanbul.

Bass, B.M. (1990). From Transactional to Transformational Leadership: Learning to Share The Vision, Organizational Dynamics, 19(3): 21.

Baron, R. M. ve Kenny, D. A. (1986). The Moderator Mediator Variable Distinction in Social Psychological Research: Conceptual, Strategic, and Statistical Considerations. Journal of Personality and Social Psychology, 51: 1173-1182.

Bildik, B. (2009). "Liderlik Tarzları, Örgütsel Sessizlik ve Örgütsel Bağlılık İlişkisi”, Gebze Yüksek Teknoloji Enstitüsü Sosyal Bilimler Enstitüsü Yayımlanmamış Yüksek Lisans Tezi, Kocaeli.

Cohen, J., Cohen, P., West, S. G. ve Aiken, L. S. (2003). Applied Multiple Regression/Correlation Analysis for the Behavioral Sciences, Mahwah, New Jersey: Lawrence Erlbaum Associates, Inc.

Çalışkan, A. ve Pekkan, N. Ü. (2017). Örgütsel Sessizliğin İş Performansına Etkisi: Etik İkliminin Aracılık Rolü, Türk Sosyal Bilimler Araştırmaları Dergisi, 2(1): 1-19.

Daşc1, E, ve Cemaloğlu, N. (2016). The development of the organizational silence scale: Validity reliability Study International Journal of Human Sciences 13(1): $32-45$.

Eddleston KS \& Kellermanns FA (2007). Destructive and productive family relationships: A stewardship theory perspective. Journal of Business Venturing 22: 545-565.

Erol, G. (2012). "Liderlik Tarzları ve Örgütsel Sessizlik İlişkisi: Otel İşletmelerinde Bir Araştırma”, Balıkesir Üniversitesi Sosyal Bilimler Enstitüsü Yayımlanmamış Yüksek Lisans Tezi, Balıkesir.

Erol, G. \& A. Köroğlu, (2013). Liderlik Tarzları ve Örgütsel Sessizlik İlişkisi: Otel İşletmelerinde Bir Araştırma, Seyahat ve Otel İşletmeciliği Dergisi/ Journal of Travel and Hospitality Management 10(3): 45-64.

Joreskog, K. G. \& Sorbom D. (1993). Lisrel 8: Structural Equation Modeling With The SIMPLIS Command Language. Chicago, IL: Scientific International Software.

Judge, T. A., Woolf, E. F., \& Hurst, C. (2009)., Is Emotional Labor More Difficult For Some Than For Others? A Multilevel, Experience-Sampling Study, Personnel Psychology, 62(1), 57-88.

Kılıç, R., B. Keklik, H. Yıldız, (2014). Dönüştürücü, Etkileşimci ve Tam Serbesti Tanıyan Liderlik Tarzlarının Örgütsel Sessizlik Üzerindeki Etkisini Belirlemeye Yönelik Bir Araştırma, Yönetim ve Ekonomi Dergisi, 21(2): 249-268. 
Kline, R. B. (1998). Principles and Practice of Structural Equation Modeling. New York: The Guilford Press.

Köse, E. K. (2013). “İlköğretim Kurumu Öğretmenlerine Göre Okul Yöneticilerinin Liderlik Stilleri İle Örgütsel Öğrenme Arasındaki İlişkide Örgütsel Sessizlik ve Karara Katılımın Aracı Etkisi”, Gazi Üniversitesi Eğitim Bilimleri Enstitüsü Yayımlanmamış Doktora Tezi, Ankara.

Luthans, F. (1995). Organizational Behavior 7. (Ed) New York Mc Graw - Hill, USA, 158-199.

Moçoşoğlu, B. \& A. Kaya, (2018). Okul Yöneticileri ve Öğretmenlerin Örgütsel Sessizlik ile Örgütsel Mutluluk Düzeyleri Arasındaki İlişki: Şanlıurfa İli Örneği, Harran Education Journal, 3(1): 52-70.

Pinder, C.C. \& Harlos, K.P., (2001). Employee Silence: Quiescence and Acquiescence as Responses to Perceived Injustice, Research in Personel and Human Research Management, 20.

Podsakoff, P. M., Mackenzie, M. S. B., ve Bommer, William H., (1996). Transformational Leader Behaviors and Substitutes for Leadership As Determinants of Employee Satisfaction, Commitment, Trust, and Organizational Citizenship Behaviors, Journal of Management, p. 22.

Podsakoff, P. M., MacKenzie, S. B. Morrman, R. H. ve Fetter, R. (1990). Transformational Leader Behaviors and their Effects on Follower's Trust in Leader Satisfaction, and Organizational Citizenship Behaviors. Leadership Quarterly, 1: 107-142.

Robbins, S. (2001). Organizational Behavior, Prentice Hall, 9.Edition, New Jersey.

Morçin, E. ve İ. Morçin, (2013). Etkileşimci Liderliğin Örgütsel Vatandaşlık Davranışına Etkisi: Adana'daki Seyahat Acenteleri Örneği,Süleyman Demirel Üniversitesi Vizyoner Dergisi, 4(9): 70-80.

Mrayyan, M. T. (2005). Nurse Job Satisfaction and Retention: Comparing Public to Private Hospitals in Jordan, Journal of Nursing Management, 13: 40-50.

Samad, S. (2006). Predicting Turnover Intentions: The Case Of Malaysian Government Doctors, The Journal Of American Academy of Business, Cambridge, 82: 113119.

Sekaran, U. (1992). Research Methods for Business, Canada: John Wiley and Sons, Inc.

Hicks, H.G., Gullett, C.R., (1981). Organizasyonlar; Teori ve Davranış, çev.Baykal, B., İstanbul, İstanbul Üniversitesi İşletme Bilimleri Enstitüsü Yayını.

Tanrıverdi, H., S. Paşaoğlu, (2014). Dönüşümcü Liderlik, Örgütsel Adalet ve İş Tatmini Arasındaki İlişkileri Belirlemeye Yönelik Okul Öncesi Öğretmenleri Üzerinde Bir Araştırma, Elektronik Sosyal Bilimler Dergisi, 13(50): 274-293.

Tengilimoğlu, D., (2005). Kamu ve Özel Sektör Örgütlerinde Liderlik Davranış1 Özelliklerinin Belirlenmesine Yönelik Bir Alan Çalışması, Elektronik Sosyal Bilimler Dergisi, 4(14), 1-16. 
Yalçınsoy, A., (2017). Örgütsel Sessizlik ve Sonuçları, Thr Journal of Social Science, 1 (1): 1-19.

Yazıcığlu, Y. ve Erdoğan, S. (2004). SPSS Uygulamalı Bilimsel Araştırma Yöntemleri. Ankara: Detay Yayıncılık.

Yıldız, M., (2002). Liderlik Yaklaşımları ve Türk Kamu Yönetiminde Liderlik Araştırmaları, Türk İdare Dergisi, 74(435), 221-246. 